\title{
RESEARCHES OF SOILSES SECONDARY CONSOLIDATION
}

\author{
Vladimir Kapustin * \\ Southwest State University, Kursk, Russia \\ Vladimir Khaustov \\ Southwest State University, Kursk, Russia \\ Vladimir K. Kapustin \\ Southwest State University, Kursk, Russia
}

If clayey soils are present in soil bases, the settlement of ground can develop during the entire service life. For the possibility of predicting the age-old sediments at the stage of engineering surveys, laboratory tests of soils in the odometer are carried out. Such tests do not fully reflect the processes occurring in the foundations of foundations of limited dimensions. For a more reliable prediction of age-old sediments, laboratory experiments are proposed not in the odometer, but in a special die assembly. The results of a long experiment with a sample of the Callovian clay of an undisturbed structure and comparison with field observations are presented.

Key words: Ground, Foundation, Base, Compressibility, Sediment, Creep

\section{INTRODUCTION}

Secondary consolidation of clay soil is shown in the form of "century" a deposit of the bases of engineering constructions. Rules of laboratory determination of coefficient of secondary consolidation are established in state standard [01]. Secondary consolidation in soil is caused by creep of a mineral skeleton of soil and natural water and colloidal communications. With certain specifics similar process of creep is observed in concrete. The technique of tests of concrete for creep [02] differs from soil not only in a type of tension of samples, but also duration of experiences. Samples of concrete are tested with a possibility of side deformations and lasting experiences not less than 180 days. At the same time deformations of creep don't reach the maximum values.

At tests of soil basic value has preservation of natural structure and humidity of samples. For carrying out experiences callovian clay of the Mikhaylovsky iron ore field is chosen as us. The age the callovian of clays corresponds to middle Jurassic deposits - about 100 million years. The Jurassic deposits are blocked by soil of quarternary age which is the bases of the majority of buildings and constructions.

Construction of unique constructions with the bases of the big sizes and the raised loadings promotes that ancient deposits can appear in an active zone of the basis.

On Mikhaylovsk career callovian clays lie within thickness of the overburden breeds blocking ferruginous quartzite. Thanks to it there is an opportunity to study their properties as the soil bases.

Since 1990 on Mikhaylovsk callovian clays are used in production of iron ore pellets that is very effective from a position of complex use of natural resources and has caused detailed studying of their properties [03].

\section{PURPOSE AND TECHNIQUE OF RESEARCHES}

The purpose of the conducted researches: to define coefficient of secondary consolidation of clay soil, to estimate change in time of speed "century" a deposit; to compare results of tests with results of natural observations; in the presence of divergences to establish their reason and to offer a technique of further tests.

Callovian clays have complex polymineral structure, belong to poorly bulking up alike bentonite clays. Engineering-geological researches have established natural heterogeneity the callovian of clays in various sites of the career field on chemical, mineral composition and physical and chemical properties [03]. At the clay layer power 


\section{INTRODUCTION}

Secondary consolidation of clay soil is shown in the form of "century" a deposit of the bases of engineering constructions. Rules of laboratory determination of coefficient of secondary consolidation are established in state standard [01]. Secondary consolidation in soil is caused by creep of a mineral skeleton of soil and natural water and colloidal communications. With certain specifics similar process of creep is observed in concrete. The technique of tests of concrete for creep [02] differs from soil not only in a type of tension of samples, but also duration of experiences. Samples of concrete are tested with a possibility of side deformations and lasting experiences not less than 180 days. At the same time deformations of creep don't reach the maximum values.

At tests of soil basic value has preservation of natural structure and humidity of samples. For carrying out experiences callovian clay of the Mikhaylovsky iron ore field is chosen as us. The age the callovian of clays corresponds to middle Jurassic deposits - about 100 million years. The Jurassic deposits are blocked by soil of quarternary age which is the bases of the majority of buildings and constructions.

Construction of unique constructions with the bases of the big sizes and the raised loadings promotes that ancient deposits can appear in an active zone of the basis.

On Mikhaylovsk career callovian clays lie within

$$
C_{a}=\operatorname{tg} \cdot \alpha=\frac{\varepsilon\left(t_{2}\right)-\varepsilon\left(t_{1}\right)}{\lg \left(t_{2}\right)-\lg \left(t_{1}\right)}=\frac{0,0860-0,0829}{5,00-3,40}=0,0019,
$$

thickness of the overburden breeds blocking fertunity to study their properties as the soil bases. ruginous quartzite. Thanks to it there is an oppor- Since 1990 on Mikhaylovsk callovian clays are

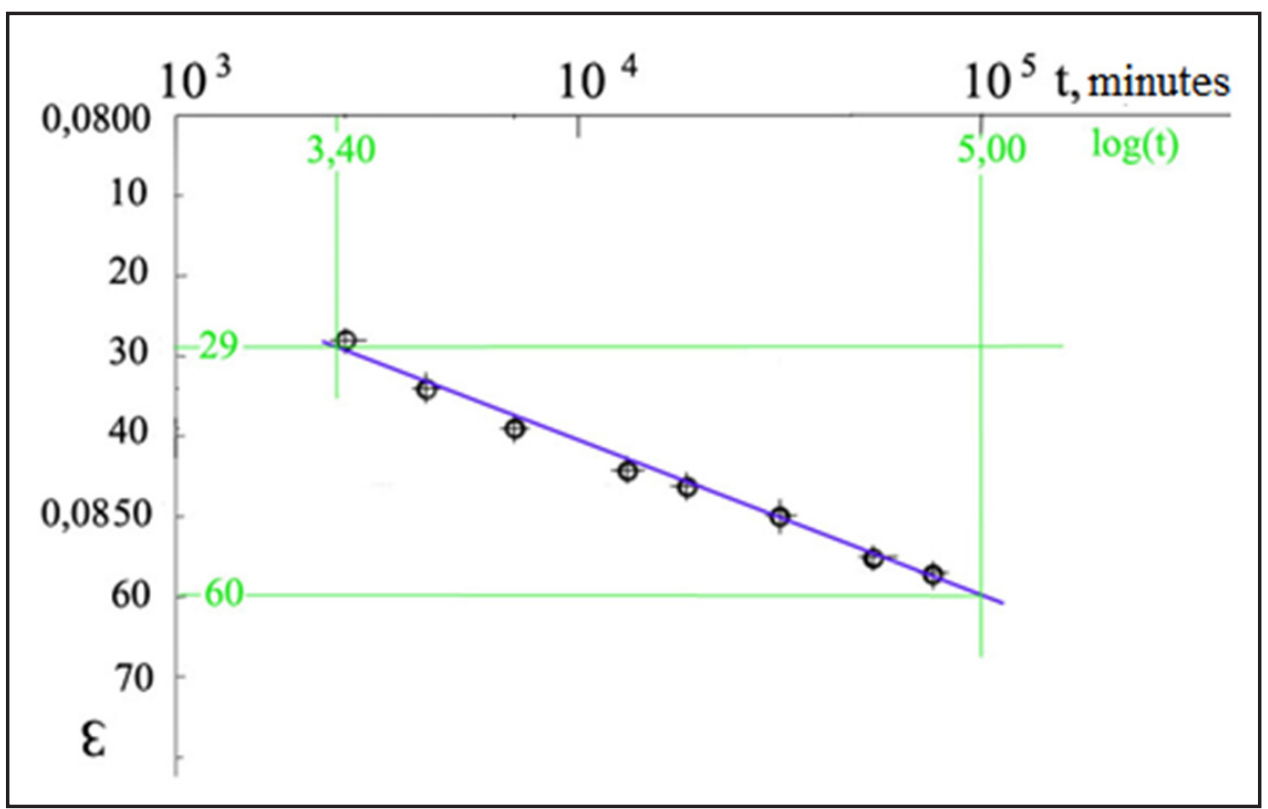

Figure 1: Schedule of processing of curve consolidation by a logarithmic method

used in production of iron ore pellets that is very effective from a position of complex use of natural resources and has caused detailed studying of their properties [03].

\section{PURPOSE AND TECHNIQUE OF RESEARCHES}

The purpose of the conducted researches: to define coefficient of secondary consolidation of clay soil, to estimate change in time of speed "cen- tury" a deposit; to compare results of tests with results of natural observations; in the presence of divergences to establish their reason and to offer a technique of further tests.

Callovian clays have complex polymineral structure, belong to poorly bulking up alike bentonite clays. Engineering-geological researches have established natural heterogeneity the callovian of clays in various sites of the career field on chemical, mineral composition and physical and 


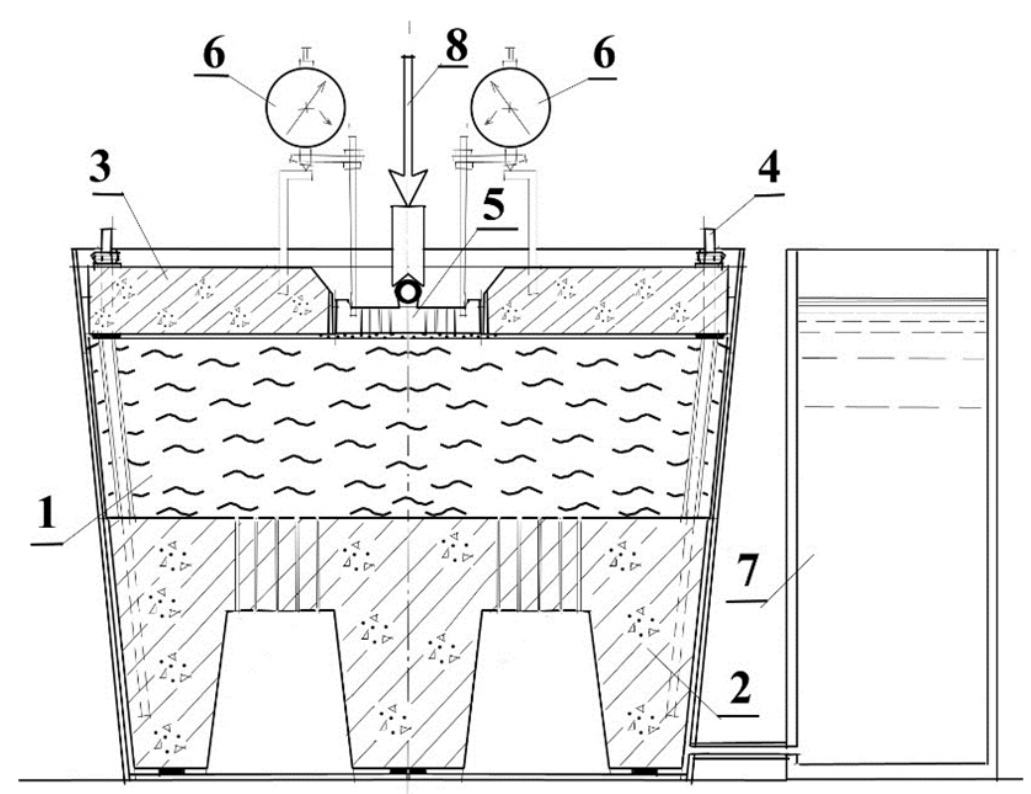

Figure 2: Laboratory stamping installation

1 sample of clay soil of undisturbed structure; 2 base of the instrument; $3^{\text {rd }}$ support plate; 4 - anchor; 5punched stamp; 6-indicator; 7-backup capacity with water; 8-axial force

chemical properties [03]. At the clay layer power in a face of 35 meters of property of clay change through each $1,5-5 \mathrm{~m}$ that testifies to extremely changeable conditions of forming of settling in the Jurassic pool. Heterogeneity is caused by

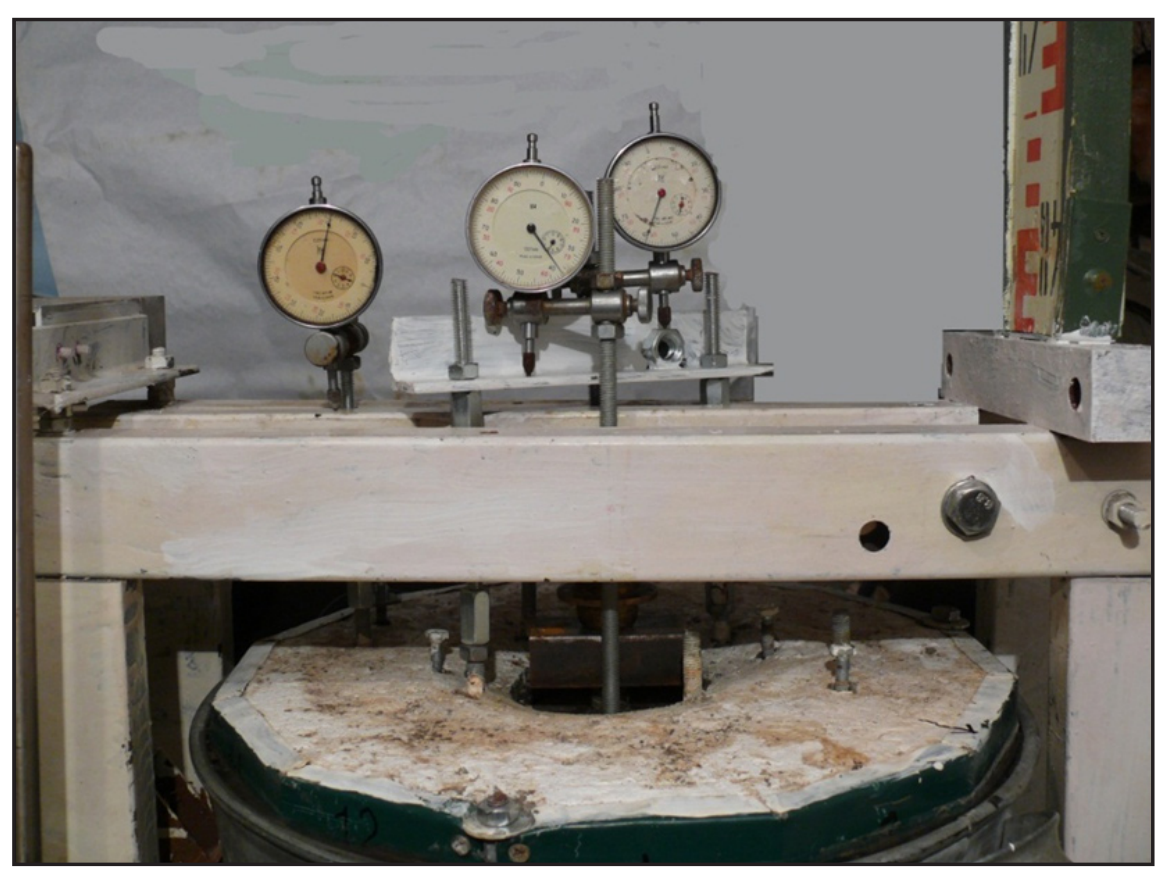

Figure 3: Measuring system of the device

unevenness of mass fractions of the main bulking-up clay mineral - montmorillonite (Al2O3 $4 \mathrm{SiO}_{2} \mathrm{n} \cdot \mathrm{H}_{2} \mathrm{O}$ ) in volume of clay. Montmorillonite forms extremely small leaflets, scales, fiberforming allocations giving to clay the increased sorption capacity in connection with a high spe- cific surface.

Authors have selected a series of samples of undisturbed structure in a dump of overburden 
Table 1: Rainfall of stamps and their speeds for a compression and volume deformation

\begin{tabular}{|l|c|c|c|c|c||c|c|c||}
\hline №№ points & 1 & 2 & 3 & 4 & 5 & 6 & 7 & 8 \\
\hline Log(t), min & 3,28 & 3,62 & 3,92 & 3,94 & 4,21 & 4,31 & 4,41 & 5,16 \\
\hline A. Compression test in odometer of «HYDROPROJECT» \\
\hline Settling SK, mm & 2,05 & 2,05 & & & & 2,14 & 2,16 \\
\hline $\begin{array}{l}\text { Speed of settling, SK1 mm/min } \\
10^{-5}\end{array}$ & 0,90 & 0,19 & & & & 0,08 & 0,01 \\
\hline B. Tests at a possibility of side expansion & 2,52 & & 2,67 & 2,73 & 2,78 & & 3,06 \\
\hline Settling Sb, mm & & & 1,6 & 0,57 & 0,57 & & 0,20 \\
\hline \hline
\end{tabular}

breeds from monoliths of callovian clay of a firm consistence for laboratory researches.

According to state standard [01, 06], for determination of coefficient of secondary consolidation (Ca) the odometer of system of the "HYDROPROJECT» was used. Pressure of $0,53 \mathrm{MPa}$ was transferred to a soil sample by one step.
Deformations of a sample were fixed on two indicators of hour type. Installation had the special platform for fastening of the camera for the purpose of macroshooting. Due to use of photofixing of movement it was possible to estimate with an accuracy of $0,001 \mathrm{~mm}$.

According to state standard [01, 06], the coeffi-

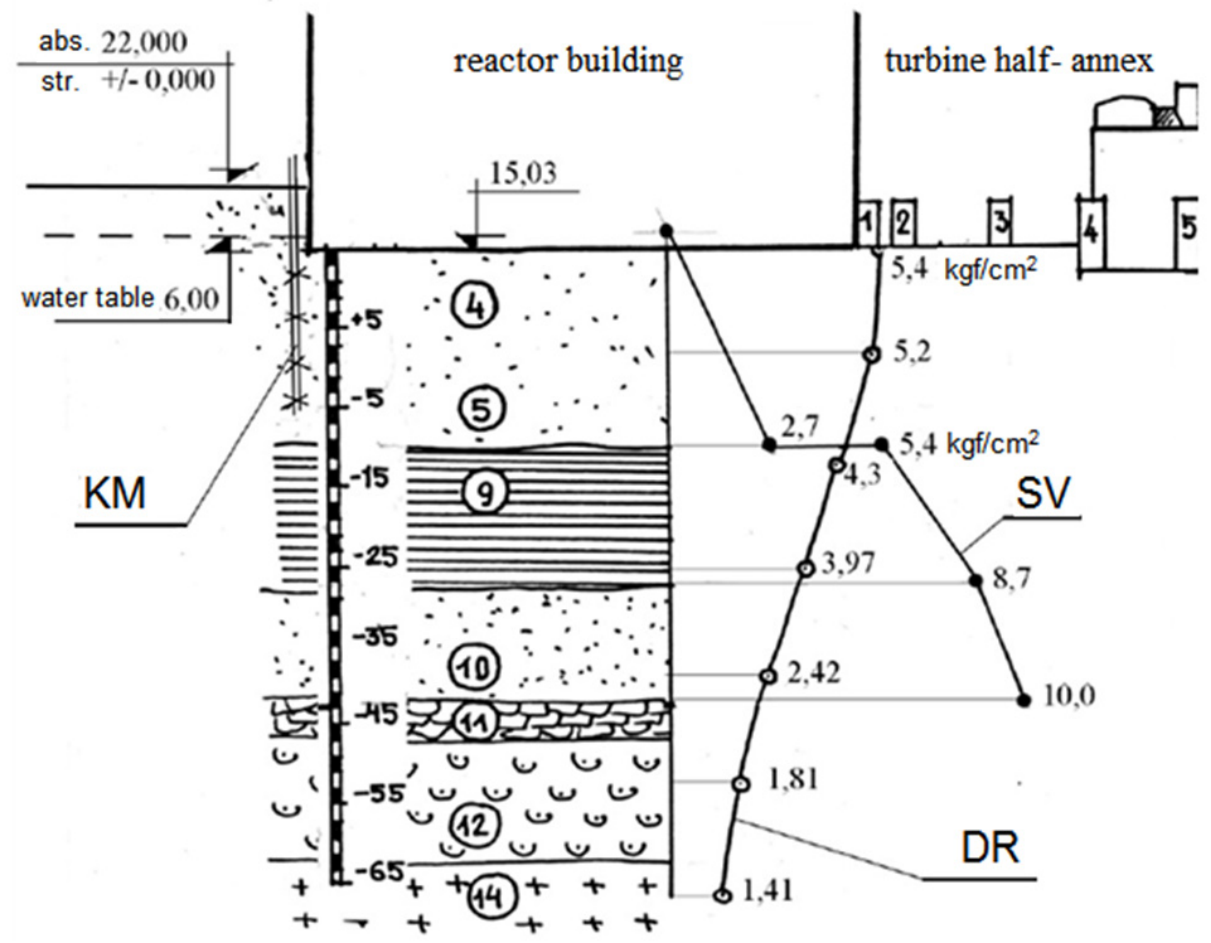

Figure 4: A section of the soil basis under the reactor building Zaporizhia NPP. DR - an epure of additional pressure from the base of the reactor building; SV - an epure of pressure from a body weight of soil; KM - a bush of deep soil brands

cient of secondary consolidation Ca (dimensionless size) is determined by an inclination tangent of angle (see Figure 1) between the line section of a curve on the site of secondary consolidation and direct parallel abscissa axis in a look:

where also values of deformation of a sample on the site of secondary consolidation; $t_{2}$ and $t_{1}$, time corresponding to deformations $\varepsilon\left(t_{2}\right)$ and $\varepsilon\left(\mathrm{t}_{1}\right)$.

\section{DESCRIPTION OF THE RESEARCH}

For pilot study of process of secondary consolidation in the conditions of difficult tension we have developed and made special laboratory stamping installation (see Figure 2). 
The base of the instrument is executed in the form of a steel concrete ribbed plate (2) on three support. When concreting a plate in it open holes for pass of water from the tank (7) are executed. Three metal anchors are connected to an accessories of a plate (4). To metal anchors the steel concrete support plate (3) fixed fastens. At plate center in case of its manufacture the brass ring on diameter of the punched stamp is put (5). Relocation of the punched stamp (5) from action of axial force (8) about two indicators of hour type (6) are measured. When carrying out experiences the photographing method on the camera of high resolution was used. It allowed to estimate relocation with an accuracy of $0,001 \mathrm{~mm}$. One of the current pictures is given in Figure 3.

As the punched working stamp of the instrument the stamp of the odometer of construction of the «HYDROPROJECT» with a diameter of $87,5 \mathrm{~mm}$ was used. Pressure upon a stamp was accepted same, as in case of compression tests [05].

The skilled monolith of soil of undisturbed structure in the form of the truncated cone had diameter on top of $340 \mathrm{~mm}$ and height of $105 \mathrm{~mm}$. He has been cut out from larger sample of the

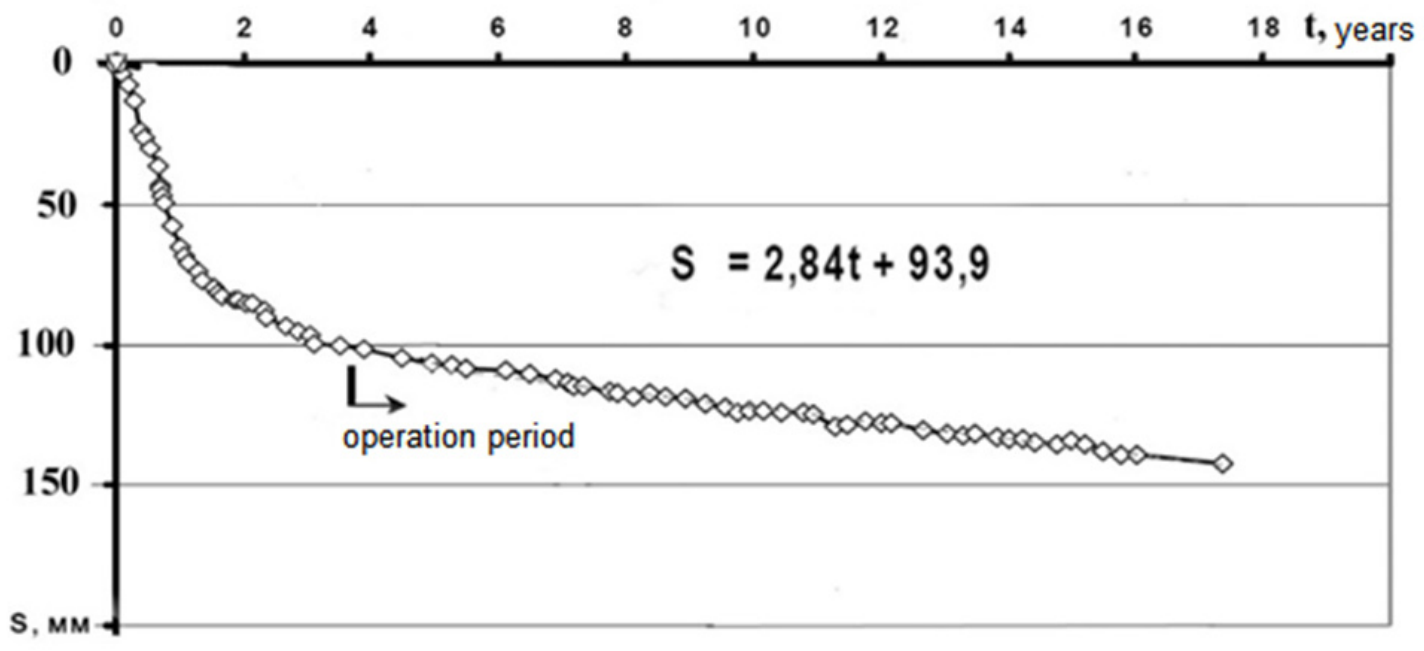

Figure 5: Schedule of development of average draft of reactor buildings Zaporizhia NPP [07]

callovian clay got when carrying out overburden works on Mikhaylovsk career.

Comparison a deposit of stamps and their speeds for a compression and spatial deformation is given in the Table 1 .

\section{ANALYSIS OF RESULTS}

The main result which follows from comparison of results of tests in various devices consists that on the expiration of 3 months of tests draft speed in the odometer is 20 times less, than at a possibility of side deformations. For deeper analysis

$$
\dot{S}=0,0019 \times \frac{\lg (t)}{\partial t} \times H_{0}=\frac{8,25 \times H_{0}}{10^{4} \times t}
$$

of secondary consolidation it is necessary to address results of natural observations of deformations of the bases of the Zaporizhia NPP.

Reactor buildings Zaporizhia NPP transfer elevated pressure to the soil bases. On a sole of their bases (see Figure 4) pressure reaches 0,54
$\mathrm{MPa}\left(5,4 \mathrm{kgfs} / \mathrm{cm}^{2}\right)$ that it is approximately twice more, than under the other bases.

When carrying out engineering researches designers have accepted that active thickness of the soil basis is in limits of the engineering geological elements "4" and " 5 ". IGE-4 - sands small, light-and yellowish-gray color, damp and water-saturated, friable, middle hearty and dense with pro-layers and lenses of dusty sands. The volume weight of sands varies from 1,85 to $2,09 \mathrm{CU} / \mathrm{m} 3$, coefficient of porosity from 0,79 to 0,5 , the module of deformation from 130 to 450 $\mathrm{kgfs} / \mathrm{cm} 2$. IGE-5 - sands of average fineness, yellow, gray and light gray, water-saturated, middle hearty and dense addition. Volume weight is $2,06 \mathrm{CU} / \mathrm{m} 3$, porosity factor 0,64 , the module of deformation of $400 \mathrm{kgfs} / \mathrm{cm}^{2}$ [03]. This soil has been most in detail investigated in field and laboratory conditions. Other engineering-geological elements when carrying out researches in details weren't investigated.

Additional natural researches [04] with use of 
deep brands have shown that the engineering geological 9 element also belongs to active thickness of the basis. IGE-9 - clay greenish-gray, layered, sandy some places. Volume weight is $1,84 \mathrm{CU} / \mathrm{m}^{3}$, porosity factor 1,014 , liquid limit 0,70 and border of a limit of plasticity 0,32 , the module of deformation of $200 \mathrm{kgfs} / \mathrm{cm}^{2}$. Besides, the deposit in the next years also tells the nature of development about inclusion in work of clay [04]. Consolidation of sandy soil comes to the end, as a rule, during the construction period.

The first block of the Zaporizhia NPP has been connected to power network on December 10, 1984. The fourth power unit finishing the first stage of construction has been connected to power network on December 18, 1987. Construction has been put "on a stream", the new power unit was entered every year. Observations of rainfall have been organized since the beginning of construction and are carried out (Figure 5) so far.

\section{CONCLUSION}

During construction and operation the list of constructions was observed. For correction of a list, the procedure of a unilateral surcharge of the bases which size in respect of $70 \times 70 \mathrm{~m}$ was already several times applied.

Knowing coefficient of secondary consolidation of clay soil it is possible to estimate change in time of speed "century" a deposit.

If to consider draft deformation of some conditional layer of $\mathrm{H}_{0}$, then dependence for draft speed on time will take place:

Where: $\mathrm{t}$ - is time of action of loading

Natural observations show other result (see fig. 5 ). Draft speed for 14 years remains approximately constant and makes $2,8 \mathrm{~mm} /$ year.

The reason of a divergence consists that in the odometer there are volume deformations, but there are no shift deformations. Therefore tests for creep need to be carried out at real existence of deformations of shift [8] for a considerable interval of time as it is accepted at tests of concrete [02].

\section{REFERENCES}

1) GOST 12248-2010. Mežgosudarstvennyj standart. Grunty. Metody laboratornogo opredeleniâ harakteristik pročnosti i deformiruemosti. - M.: Standartinform, 2012, 78 s.
2) GOST 24544-81*(1987). Betony. Metody opredeleniâ deformacij usadki i polzučesti. - M.: 1987, 24 s.

3) Altynbaev, R. A., Gzogân, S. R., Mel'nikova, N. D. (2001). Ispol'zovanie kellovejskih glin pri proizvodstve železorudnyh okatyšej. Gornyj informacionno-analitičeskij bûlleten' (naučno-tehničeskij žurnal). № 4, 76-80.

4) Kapustin, V.K. (2012). Geotehničeskij kontrol' gruntovogo osnovaniâ Zaporožskoj AÈS. Izvestiâ Ûgo-Zap. gos. un-t., seriâ tehnika i tehnologiâ. № 2, 222-225.

5) Opredelenie koèfficientov konsolidacii kellovejskoj gliny po ispytaniâm $\mathrm{v}$ odometer (texisyi doklada) / Kapustin, V.V., Špil'ko, A.A., Kapustin, V.K./ Buduŝee nauki-2016: Sbornik naučnyh statej 4-j Meždunarodnoj molodežnoj naučnoj konferencii (14-15 aprelâ 2016 goda), v 4-h tomah, Tom 3, Ûgo-Zap. gos. un-t., ZAO «Universitetskaâ kniga». Kursk, 2016. - S 274. ISBN 978-5-99079487-0.

6) Osnovaniâ zdanij i sooruženij / SP 22.13330.2011. - M., 2011, $166 \mathrm{~s}$.

7) Sedin, V.L., Bausk, E.A., Golovko, S.I. (2010). Ocenka tehničeskogo sostoâniâ i prodlenie èkspluatacii fundamenta zaŝitnoj oboločki reaktornogo otdeleniâ VVÈR-1000. Vestnik PGASA. №9, 39-45.

8) Ter - Martirosân, A. Z. (2016). Vzaimodejstvie fundamentov zdanij i sooruženij s vodonasyŝennym osnovaniem pri učete nelinejnyh i reologičeskih svojstv gruntov / Dissertaciâ na soiskanie učenoj stepeni doktora tehničeskih nauk. - M., 324 s.

Paper sent to revision: 04.07.2017.

Paper ready for publication: 04.09.2017. 